Dokuz Eylül Üniversitesi-Mühendislik Fakültesi

Fen ve Mühendislik Dergisi

Cilt 20, Sayı 58, Ocak, 2018
Dokuz Eylul University-Faculty of Engineering Journal of Science and Engineering Volume 20, Issue 58, January, 2018

DOI: $10.21205 /$ deufmd. 2018205802

\title{
Gediz Havzası'nda Yıllık Bitki Deseni Değişimlerinin Ekonomik Nedenleri ve Sulama Suyu Talebine Etkileri
}

\section{Cem Polat ÇETINKAYA*1, Mert Can GÜNAÇTI ${ }^{2}$}

${ }^{1}$ Dokuz Eylül Üniversitesi, Mühendislik Fakültesi, İnșaat Mühendisliği Bölümü, 35390, İzmir (ORCID: 0000-0002-8586-3168)

2Dokuz Eylül Üniversitesi, Mühendislik Fakültesi, İnșaat Mühendisliği Bölümü, 35390, İzmir (ORCID: 0000-0002-2754-7271)

(Alınış / Received: 23.01.2017, Kabul / Accepted: 21.04.2017,

Online Yayınlanma / Published Online: 20.01.2018)

Anahtar Kelimeler Özet: Gediz Havzası'nda yıllar içinde yaşanan farklı şiddetlerdeki Gediz, Regresyon Analizi, Sulama Suyu İhtiyacl, Tarımsal Bitki Deseni kuraklıklar, havzanın orta ve aşağı kısımlarında bulunan yaklașık 110000 hektar sulama alanında sürdürülen tarımsal faaliyetleri etkilemiştir. Yapılan çalışmada, 1995-2012 yılları arasında Gediz Havzası'nda tarımsal sulama yapılan alanların büyüklüğünde, ürün alım fiyatlarında, bitki deseninde ve sulama suyuna olan ihtiyaçta yaşanan değişimler tespit edilmiş ve aralarındaki iliş̧kiler doğrusal regresyon yöntemiyle irdelenmiştir. Bitki deseni değişimlerinde bir önceki yılın ürün fiyatları ile doğrudan bir iliş̧i bulunduğu, çiftçinin buna göre davrandığ ve sonucunda havzadaki hâkim ürün önceliğinin değiștiği belirlenmiştir. Ayrıca ürün desenindeki değişim sonucunda aylık sulama suyu tahsis planlarının etkileneceği, pik su ihtiyacı değerlerinin ve tarihlerinin değișeceği vurgulanmıștır.

\section{Economical Grounds of Annual Crop Pattern Changes and Its Effects on Irrigation Water Demands in Gediz Basin}

\begin{tabular}{|c|c|}
\hline $\begin{array}{l}\text { Keywords } \\
\text { Gediz, } \\
\text { Regression } \\
\text { Analysis, } \\
\text { Irrigation Water } \\
\text { Demand, } \\
\text { Agricultural Crop } \\
\text { Pattern }\end{array}$ & $\begin{array}{l}\text { Abstract: Through out the years in Gediz river basin, droughts of } \\
\text { different severities have been influential on approximately } \\
100000 \text { hectars of irrigation areas located in the middle and the } \\
\text { lower regions of the basin on agricultural activies. In this study, } \\
\text { the changes and the interrelations of agriculturally irrigated areas, } \\
\text { crop purchase prices, crop patterns and crop water demands in } \\
\text { Gediz river basin between years } 1995-2012 \text { have been } \\
\text { determined and examined by regression analysis. It has been } \\
\text { detected that, there exists a relationship between crop pattern } \\
\text { changes and previous years crop prices and the farmers behave } \\
\text { according to it, thus changing the prior crop in the basin's pattern. } \\
\text { Also it has been discovered that, change in the crop pattern also } \\
\text { changes the peak irrigation water amount and it's date, thus the } \\
\text { water allocation plans of the basin. }\end{array}$ \\
\hline
\end{tabular}

*Sorumlu yazar: Cem Polat Çetinkaya: cem.cetinkaya@deu.edu.tr 


\section{Giriş}

Tarımsal sulama, bitki gelișimi için gerekli olan ve doğal yollarla karşılanamayan suyun toprağa verilmesi olarak tanımlanabilir. Sulamada esas, bitki su ihtiyacının belirlenmesidir. Bitkilerin su tüketimleri, türlere göre değişiklik gösterdiği gibi, aynı bitki için yöre, iklim ve gelişim faktörlerine göre de değişiklik gösterebilmektedir. $\mathrm{Bu}$ nedenle çeşitli bitkilerin değişik iklimlerdeki su tüketimlerinin bilinmesi, sulama tesisinin planlanması ve projelendirilmesi su ekonomisi yönünden de önem taşımaktadır [1].

Ülkemizin iklim verileri, tarım alanlarının \% 96'sının bitki yetişme döneminde yeterli yağış almadığını göstermektedir. $\mathrm{Bu}$ durum sulamanın önemini artırmaktadır [2].

Türkiye'nin Batı Anadolu'sunda yer alan Gediz Havzası, yarı kurak bir iklime sahiptir. Bu tip bölgelerde ise erișilebilir su kaynakları tarımsal faaliyetleri kısıtlayan başlıca unsurlardandır [3]. Havzada, 1989 yılında başlayan ve 1994'e kadar devam eden kurak dönem, beraberinde sulama suyu açısından kullanıcılar arasında yoğun bir rekabeti de getirmiştir. Havzadaki suyun ana tüketicisi olan ve yaklaşık 110000 hektar alana sahip tarım sektörü her geçen yll artan ve gelişen evsel ve endüstriyel su talepleri ile rekabet halindedir. Havzanın ana problemi su kirliliği olsa da, zaman zaman yaşanan çeşitli şiddet ve sürelerdeki kuraklıklar, su tahsisinde sıkıntılara ve ekonomik kayıplara yol açmaktadır [4].

$\mathrm{Bu}$ ve benzeri problemlerin çözümleri, sürdürülebilir kalkınma, sosyal denge ve eşitlik boyutlarının gözetilmesiyle aranmalıdır [5]. Sürdürülebilir kalkınma bugün ve geleceğin ekonomik, sosyal ve çevresel problemlerine bütünleşik olarak çözüm arayan bir anlayışı tanımlamaktadır [6]. Dolayısıyla ortaya "Su güvenliği" kavramı bir kilit eleman olarak çıkmaktadır. Su güvenliği, tanımınca su altyapısı, tahsisi ve yönetimini farklı seviyelerde (bölgesel, ulusal veya uluslar arası) kapsamaktadır [7]. Bu açıdan bakıldığında, yapılan çalışma zaman içinde su talebinin değişim desenlerini inceleyerek, su tahsisi stratejilerinin geliştirilmesine ön ayak olmayı hedeflemektedir.

Havzada yıllar içinde tarımsal faaliyetler ve buna bağlı olarak sulama değişimleri incelendiğinde, görülmektedir ki; bakım onarım maliyetleri ve bazı bölgelerde karșılașılan kısıtlı yüzeysel su miktarı nedeniyle, havzadaki sulama alanları 1995-2012 yılları arası süreçte potansiyel kapasitesinin yarısına kadar düşmüștür [8].

$\mathrm{Bu}$ ve benzeri sorunlar, tarımla uğraşan toplum kesimlerinin geleneksel olarak yetiștirdikleri bitki desenlerini değiştirmeye itmiştir. Yıllar içinde gelişen bu değişimin önemli sonuçları olmuştur. Tarımsal su talebi açısından bakıldığında, bu değişimin aylık ölçekte miktar ve zamanlamada değişiklik yaratacağı açıktır.

Yapılan çalışmada, yaşanan bu değişimin nedenselliği farklı yöntemlerin birarada kullanılmasıyla irdelenmiş ve belirlenmeye çalışılmıştır.

Çalıșma kapsamında öncelikli olarak pamuk, mısır ve bağ alanları için yıllık toplam alansal değișimler sunulmuștur. Devamında ise, sulama alanlarındaki değișimler ile ürün alım fiyatları arasında bir ilișki olup olmadığı, sulama alanları ile ürün alım fiyatları arasında doğrusal regresyon analizi yapilarak değerlendirilmiştir. Ayrıca bir önceki yıl alım fiyatı ile bulunan yıl verileri birleștirilerek yeniden regresyon analizi yapılmış, üreticinin ürün deseni seçerken 

Suyu Talebine Etkileri

bir önceki yıl fiyatlarından etkilenip etkilenmediği değerlendirilmiştir.

Son olarak, yıllar içinde bitki bazında ve toplamdaki sulama suyu ihtiyaçları hesaplanıp, ortaya çıkan değişimler ve bu durumu etkileyen politikalar tartışılmış, ortaya çıkan bitki deseninin sulama takvimi ve aylık/yıllık su taleplerine etkisi irdelenmiștir.

\section{Materyal ve Metot}

\section{1. Çalışma Alanı}

Batı Anadolu'da bulanan Gediz Havzası (Şekil 1), Ege denizi, Küçük menderes ve
Bakırçay havzaları arasında yer almaktadır. Havza, kuzey, güney ve doğudan yükseklikleri 2000 m'yi bulan dağlar, batıda ise Ege denizi tarafından çevrelenmiştir. Gediz nehrinin uzunluğu $276 \mathrm{~km}$ ve toplam drenaj alanı 16775 $\mathrm{km}^{2}$ 'dir. Nehrin ana kollarını Deliniş, Selendi, Demirci, Nif, Alașehir ve Kumçay akarsuları oluşturur. Adala, Ahmetli, Menemen, Akhisar, Selendi, Kapaklı ve Alaşehir ovaları aşağı Gediz ovalarını oluştururlar. Bu ovalar 110000 hektarlık büyük sulama alanlarına sahip geniş tarımsal faaliyetler için kullanılmaktadır.

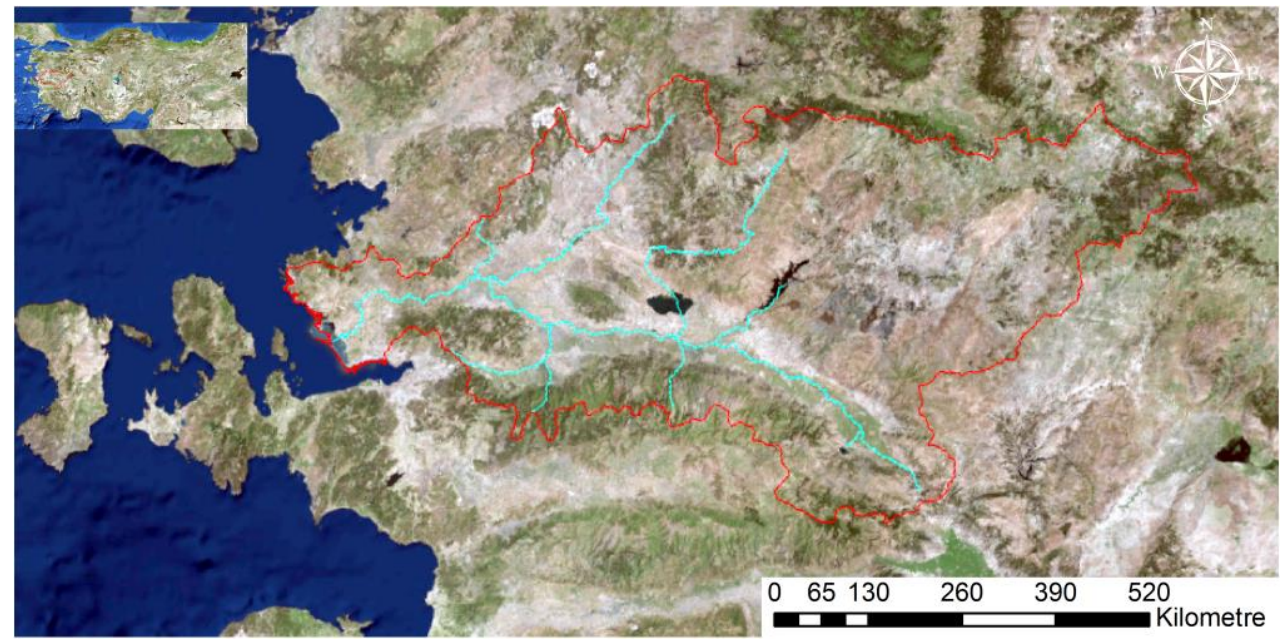

Şekil 1. Gediz Havzası

Gediz havzasında yazlar sıcak ve kurak, kışlar ise ılık ve yağmurlu, tipik bir Akdeniz iklimi hükmü altındadır. Yıllık yağış değerleri bölgeden bölgeye 492 mm (Salihli) - $726 \mathrm{~mm}$ (Manisa) değerleri arasında değişmektedir. Yıllık yağış değerleri ortalama olarak 635 mm'dir. Ylllık yağış değerlerinin \%75'i kasım ve mayıs ayları arasındaki beş aylık dönemde oluşur [9].

Havzada toplam 14 adet sulama birliği bulunmaktadır ve yapılan çalışmada bu 14 sulama birliğinin toplam verileri dikkate alınmıştır. Çalışmaya konu olan sulama alanlarının, boyutu yaklaşık olarak 70000 hektara ulaşmakta, bu da Gediz Havzası'ndaki toplam sulama alanlarının \%65'ini temsil etmektedir.

\subsection{Basit doğrusal regresyon analizi}

Çalışmada kullanılan basit doğrusal regresyon analizinde iki değişken arasında doğrusal bir ilişki bulunduğu kabul edilmektedir. Değișkenler arasında doğrusal istatistik bir bağımlılık bulunmasını beklendiği üzere, aynı gözlemde ölçülen değer çiftlerinin düzlemde birer nokta ile işaretlenmesi sonucu elde edilen noktaların bir doğru çevresinde bir yayılma ile dağılmaları, değişkenler arasında doğrusal bir ilişki 
bulunduğunu göstermektedir. Ancak iki rastgele değişken arasında anlamlı bir ilişki bulunup bulunmadığına karar vermek için sadece gözlenmiş değer çiftlerini noktalamak yeterli değildir. $\mathrm{Bu}$ amaçla korelasyon katsayıları da hesaplanıp irdelenmiștir.

Korelasyon katsayısı hesaplanırken aşağıdaki bağıntı (1) kullanılmıştır:

$$
r_{z, y}=\frac{\sum_{i=1}^{N}\left(x_{i}-\bar{x}\right)\left(y_{i}-\bar{y}\right)}{N \times S_{z} \times S_{y}}
$$

Burada,

$r_{\mathrm{r}_{\mathrm{s}} y}=$ Korelasyon katsayısı

$x_{i}=$ i'inci x değeri

$y_{i}=$ i'inci y değeri

$\bar{x}=\mathrm{x}$ değerlerinin ortalaması

$\bar{y}=\mathrm{y}$ değerlerinin ortalaması

$S_{\text {政 }}=\mathrm{x}$ değerlerinin standart sapması

$s_{y}=$ y değerlerinin standart sapması

$\mathbb{N}=$ Örnek sayısı

\subsection{Fiyat Endekslemesi}

Endeks belirli bir olaya ait sayısal verilerde zaman veya mekân boyutunda meydana gelen oransal değişimin göstergesi olarak tanımlanabilir. Fiyat endekslemesi de benzer şekilde, söz konusu başlangıç yılını esas alarak ileri tarihteki yıllarda fiyatın temel alınan yıla bağlı alım gücü açısından artış veya azalıșını kullanılmaktadır [10].

Çalışma kapsamında yapılan hesaplamalarda 1994 yll, temel (baz) yıl kabul edilmiştir. 1994 yılı ürün alım fiyatı 1 olarak kabul edilip, yıllık ortalama enflasyon oranı kullanılarak sonraki yıllarda temel fiyatın enflasyon oranı artışına göre ne kadar olması gerektiği aşağıdaki gibi hesaplanmıştır.

$$
X_{\mathrm{i}}=X_{\mathrm{i}-1}+e \times X_{\mathrm{i}-1}
$$

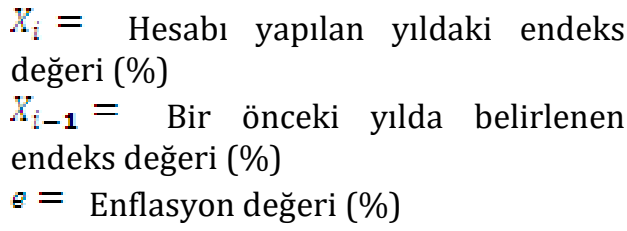

$\mathbb{X}_{\mathrm{I}}=$ Hesabı yapılan yıldaki endeks değeri (\%)

$X_{i-1}=$ Bir önceki yılda belirlenen endeks değeri (\%)

$e=$ Enflasyon değeri (\%)

\section{Bulgular}

\subsection{Sulama alanlarındaki mevcut durum}

Gediz Havzası'nda toplam 14 sulama birliği bulunmaktadır. Ancak söz konusu sulama birliklerinden 12 tanesinin verileri ele alınarak incelenmiştir. Bunun sebebi, incelemeye alınmayacak olan sulama birliklerinde sadece bir tek hâkim ürün çeşidinin olmasıdır ve üreticinin başka bir tarım ürünü ekmeye ihtiyaç duymamasıdır. İncelenen Gediz Havzası sulanan toplam ürün alanlarının yıllara göre değișimi Tablo 1, 2'de verilmiștir. Yüzde cinsinden değerleri ise Tablo 3, 4'de gösterilmiştir.

Tablo 1, 2 incelendiğinde havzada genel olarak pamuk, bağ ve misır ekildiği görülmektedir. Ekilen alanların yaklaşık \%90'ını oluşturan bu üç ürün dışında meyve, sebze, hububat vb. ürünler de ekilmekte ancak bu ürünlerin havza genelinde toplam ekim alanları göz ardı edilebilir oranlarda kalmakta ve yıldan yıla önemli değişimler gözlenmemektedir. Bu nedenle çalışma pamuk, mısır ve bağ hâkim ürünleri üzerine yapılmıştır.

Şekil 2 ve 3 incelendiğinde toplam sulanan alanlardaki artışa rağmen pamuk sulama alanlarında kararlı bir azalma gözlenmektedir. Bu azalmaya karşı mısır sulama alanlarında yıllar içinde gelişen bir artıș söz konusudur (Șekil 4). İlk bakıșta, geçmiște pamuk eken çiftçinin tercihinin seneler içinde değiștiği, eğilimin büyük oranda mısıra kaydığg görülmektedir (Şekil 6). Ayrıca bağ alanlarındaki düşüşün sebebi ise toplam alanlardaki azalmaya bağlanabilir (Şekil 5). 
C.P. Çetinkaya vd. / Gediz Havzası'nda Yıllık Bitki Deseni Değişimlerinin Ekonomik Nedenleri ve Sulama Suyu Talebine Etkileri

Tablo 1. Gediz Havzası'nda yıllara göre sulanan ürün alanları (ha) (1995-2003 yılları arası)

\begin{tabular}{|c|c|c|c|c|c|c|c|c|c|}
\hline & 1995 & 1996 & 1997 & 1998 & 1999 & 2000 & 2001 & 2002 & 2003 \\
\hline Pamuk & 36004 & 36691 & 32538 & 35081 & 32065 & 26670 & 31166 & 32060 & 28490 \\
\hline Bağ & 22727 & 23778 & 21586 & 22915 & 22723 & 25753 & 24990 & 25895 & 25530 \\
\hline Misır & 1105 & 1656 & 2819 & 2715 & 3424 & 5847 & 4612 & 5763 & 7790 \\
\hline Meyve & 1179 & 1310 & 1120 & 1238 & 1205 & 1253 & 1151 & 1278 & 1216 \\
\hline Bostan & 607 & 143 & 305 & 472 & 430 & 856 & 789 & 709 & 492 \\
\hline Sebze & 1000 & 1385 & 834 & 1742 & 1600 & 1774 & 1599 & 1978 & 1934 \\
\hline Hububat & 54 & 829 & 539 & 224 & 460 & 1174 & 853 & 717 & 924 \\
\hline $\begin{array}{l}\text { Hayvan } \\
\text { Yemi }\end{array}$ & 77 & 83 & 352 & 275 & 492 & 400 & 327 & 930 & 281 \\
\hline Narenciye & 763 & 657 & 663 & 741 & 709 & 709 & 729 & 453 & 761 \\
\hline Tütün & 0 & 0 & 0 & 0 & 0 & 20 & 1 & 5 & 1 \\
\hline Şeker Pan. & 0 & 140 & 79 & 63 & 64 & 114 & 79 & 27 & 35 \\
\hline $\begin{array}{c}\text { Mevsim } \\
\text { Dışı Sulama }\end{array}$ & 858 & 901 & 1204 & 725 & 758 & 1952 & 512 & 5 & 744 \\
\hline Çayır/Mera & 0 & 0 & 0 & 0 & 0 & 0 & 0 & 0 & 0 \\
\hline Zeytinlik & 0 & 0 & 0 & 0 & 0 & 0 & 0 & 0 & 0 \\
\hline Diğer & 1397 & 1210 & 748 & 688 & 1546 & 355 & 239 & 764 & 917 \\
\hline 2.Ürün & 0 & 0 & 0 & 0 & 0 & 0 & 0 & 0 & 0 \\
\hline Toplam & 65771 & 68783 & 62787 & 66879 & 65476 & 66877 & 67047 & 70584 & 69115 \\
\hline
\end{tabular}

Tablo 2. Gediz Havzası'nda yıllara göre sulanan ürün alanları (ha) (2004-2012 yılları arası)

\begin{tabular}{|c|c|c|c|c|c|c|c|c|c|}
\hline & 2004 & 2005 & 2006 & 2007 & 2008 & 2009 & 2010 & 2011 & 2012 \\
\hline Pamuk & 27300 & 24427 & 21553 & 10621 & 6846 & 6980 & 12185 & 6783 & 1380 \\
\hline Bağ & 26091 & 23621 & 21150 & 17465 & 15277 & 17900 & 15953 & 16578 & 17203 \\
\hline Misır & 9822 & 12907 & 15993 & 18361 & 12594 & 15136 & 17073 & 17890 & 18707 \\
\hline Meyve & 1592 & 1782 & 1972 & 2183 & 1417 & 2122 & 2320 & 1980 & 1639 \\
\hline Bostan & 428 & 481 & 534 & 412 & 822 & 902 & 604 & 597 & 590 \\
\hline Sebze & 2180 & 2603 & 3026 & 1992 & 1783 & 2712 & 2580 & 2311 & 2042 \\
\hline Hububat & 4872 & 4770 & 4667 & 2447 & 2961 & 857 & 2198 & 1972 & 1747 \\
\hline $\begin{array}{l}\text { Hayvan } \\
\text { Yemi }\end{array}$ & 1072 & 927 & 782 & 792 & 531 & 713 & 473 & 402 & 331 \\
\hline Narenciye & 633 & 317 & 0 & 0 & 0 & 0 & 195 & 98 & 0 \\
\hline Tütün & 838 & 419 & 0 & 0 & 0 & 0 & 0 & 0 & 0 \\
\hline Şeker Pan. & 75 & 38 & 0 & 0 & 0 & 0 & 0 & 0 & 0 \\
\hline $\begin{array}{c}\text { Mevsim } \\
\text { Dişı Sulama }\end{array}$ & 79 & 40 & 0 & 0 & 0 & 0 & 0 & 599 & 1198 \\
\hline Çayır/Mera & 0 & 306 & 612 & 0 & 0 & 582 & 640 & 615 & 590 \\
\hline Zeytinlik & 0 & 0 & 0 & 0 & 0 & 0 & 195 & 98 & 0 \\
\hline Diğer & 144 & 871 & 1598 & 1165 & 797 & 958 & 318 & 242 & 165 \\
\hline 2.Ürün & 0 & 0 & 4868 & 228 & 228 & 1370 & 1370 & 1741 & 2112 \\
\hline Toplam & 75126 & 73507 & 76756 & 55665 & 43256 & 50231 & 56105 & 51904 & 47703 \\
\hline
\end{tabular}


C.P. Çetinkaya vd. / Gediz Havzası'nda Yıllık Bitki Deseni Değişimlerinin Ekonomik Nedenleri ve Sulama Suyu Talebine Etkileri

Tablo 3. Gediz Havzası'nda yıllara göre sulanan ürün alanları (\%) (1995-2003 yılları arası)

\begin{tabular}{cccccccccc}
\hline & 1995 & 1996 & 1997 & 1998 & 1999 & 2000 & 2001 & 2002 & 2003 \\
Pamuk & 55 & 53 & 52 & 52 & 49 & 40 & 46 & 45 & 41 \\
Bağ & 35 & 35 & 34 & 34 & 35 & 39 & 37 & 37 & 37 \\
Mısır & 2 & 2 & 4 & 4 & 5 & 9 & 7 & 8 & 11 \\
Meyve & 2 & 2 & 2 & 2 & 2 & 2 & 2 & 2 & 2 \\
Bostan & 1 & 0 & 0 & 1 & 1 & 1 & 1 & 1 & 1 \\
Sebze & 2 & 2 & 1 & 3 & 2 & 3 & 2 & 3 & 3 \\
Hububat & 0 & 1 & 1 & 0 & 1 & 2 & 1 & 1 & 1 \\
Hayvan Yemi & 0 & 0 & 1 & 0 & 1 & 1 & 0 & 1 & 0 \\
Narenciye & 1 & 1 & 1 & 1 & 1 & 1 & 1 & 1 & 1 \\
Tütün & 0 & 0 & 0 & 0 & 0 & 0 & 0 & 0 & 0 \\
Şeker Pan. & 0 & 0 & 0 & 0 & 0 & 0 & 0 & 0 & 0 \\
Mevsim Dișı Sulama & 1 & 1 & 2 & 1 & 1 & 3 & 1 & 0 & 1 \\
Çayır/Mera & 0 & 0 & 0 & 0 & 0 & 0 & 0 & 0 & 0 \\
Zeytinlik & 0 & 0 & 0 & 0 & 0 & 0 & 0 & 0 & 0 \\
Diğer & 2 & 2 & 1 & 1 & 2 & 1 & 0 & 1 & 1 \\
2.Ürün & 0 & 0 & 0 & 0 & 0 & 0 & 0 & 0 & 0 \\
Toplam & 100 & 100 & 100 & 100 & 100 & 100 & 100 & 100 & 100 \\
\hline
\end{tabular}

Tablo 4. Gediz Havzası'nda yıllara göre sulanan ürün alanları (\%) (2004-2012 yılları arası)

\begin{tabular}{ccccccccccc}
\hline & 2004 & 2005 & 2006 & 2007 & 2008 & 2009 & 2010 & 2011 & 2012 \\
Pamuk & 36 & 32 & 28 & 19 & 16 & 14 & 22 & 15 & 3 \\
Bağ & 35 & 32 & 28 & 31 & 35 & 36 & 28 & 32 & 36 \\
Mısır & 13 & 18 & 21 & 33 & 29 & 30 & 30 & 34 & 39 \\
Meyve & 2 & 2 & 3 & 4 & 3 & 4 & 4 & 4 & 3 \\
Bostan & 1 & 1 & 1 & 1 & 2 & 2 & 1 & 1 & 1 \\
Sebze & 3 & 4 & 4 & 4 & 4 & 5 & 5 & 4 & 4 \\
Hububat & 6 & 6 & 6 & 4 & 7 & 2 & 4 & 4 & 4 \\
Hayvan Yemi & 1 & 1 & 1 & 1 & 1 & 1 & 1 & 1 & 1 \\
Narenciye & 1 & 0 & 0 & 0 & 0 & 0 & 0 & 0 & 0 \\
Tütün & 1 & 1 & 0 & 0 & 0 & 0 & 0 & 0 & 0 \\
Şeker Pan. & 0 & 0 & 0 & 0 & 0 & 0 & 0 & 0 & 0 \\
Mevsim Dişı Sulama & 0 & 0 & 0 & 0 & 0 & 0 & 0 & 1 & 3 \\
Çayır/Mera & 0 & 0 & 1 & 0 & 0 & 1 & 1 & 1 & 1 \\
Zeytinlik & 0 & 0 & 0 & 0 & 0 & 0 & 0 & 0 & 0
\end{tabular}


C.P. Çetinkaya vd. / Gediz Havzası'nda Yıllık Bitki Deseni Değişimlerinin Ekonomik Nedenleri ve Sulama Suyu Talebine Etkileri

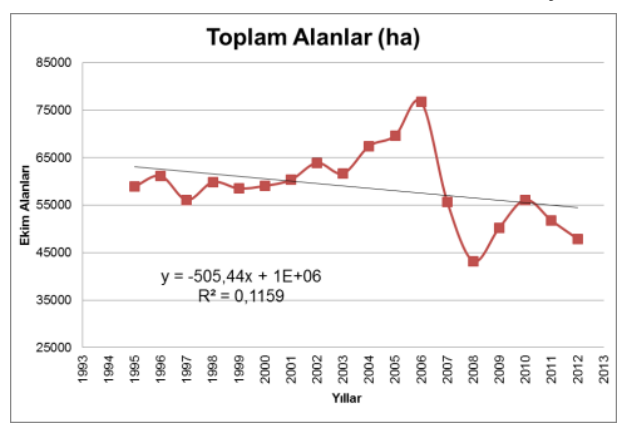

Şekil 2. Gediz Havzası'nda toplam sulanan alanların yıllara göre değişimi

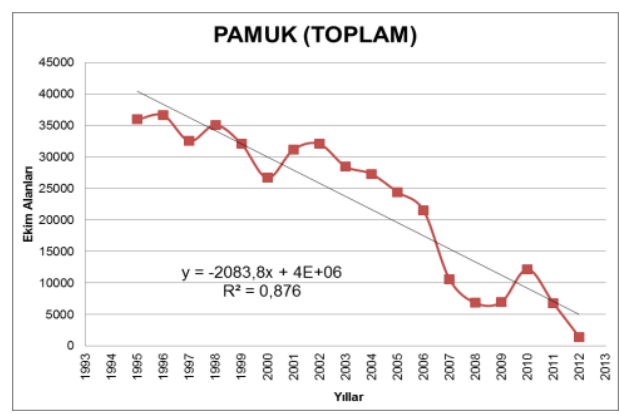

Şekil 3. Gediz Havzası'nda toplam sulanan pamuk alanlarının yıllara göre değişimi (ha)

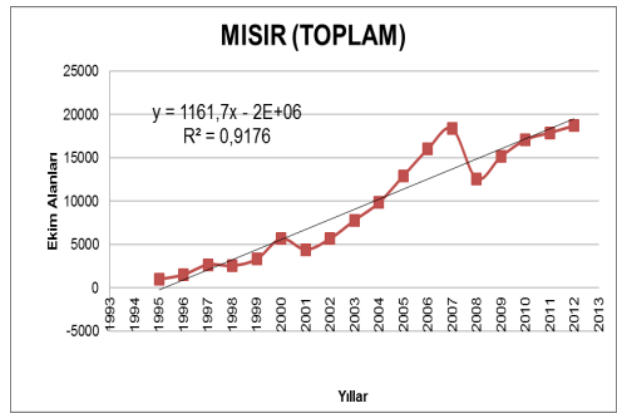

Şekil 4. Gediz Havzası'nda toplam sulanan mısır alanlarının yıllara göre değişimi (ha)

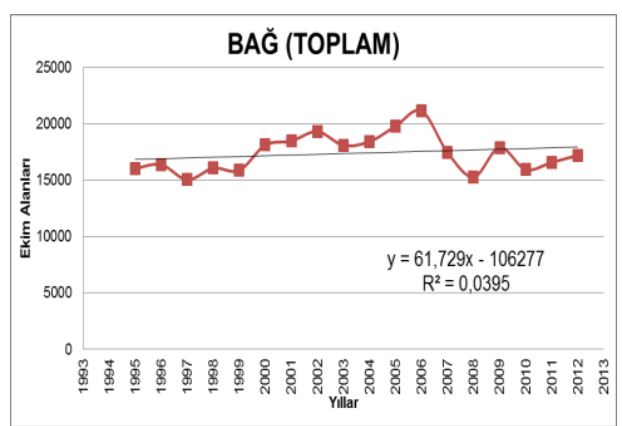

Sekil 5. Gediz Havzası'nda toplam sulanan bağ alanlarının yıllara göre değişimi (ha)

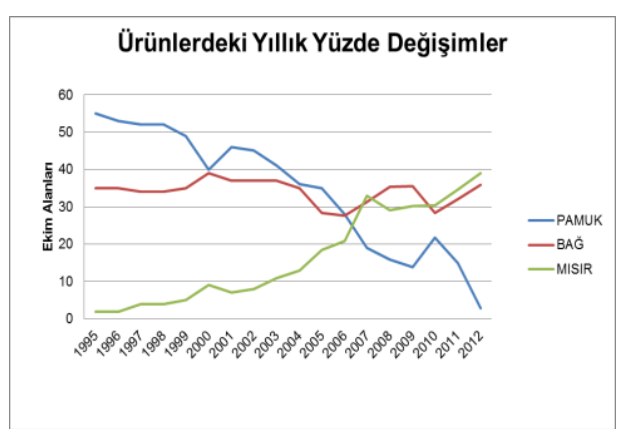

Şekil 6. Gediz Havzası'nda toplam sulanan pamuk, mısır ve bağ alanlarının yıllara göre yüzde cinsinden değișimi

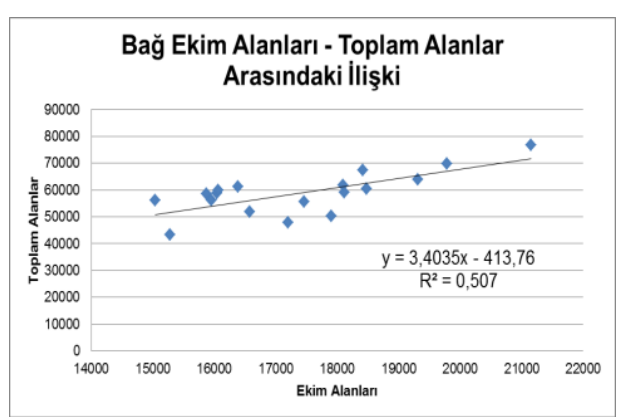

Şekil 7. Gediz Havzası'nda toplam sulanan bağ alanlarının toplam sulanan alanlara göre değişimi

\subsection{Fiyat endekslerinin bulunması}

\subsubsection{Yıllık ürün alım fiyatları}

Çalışmanın devamındaki ekonomik hesaplamalarda, 1994-2012 yılları arası ürün alım fiyatları dikkate alınmıştır. Çalıșmaya konu olan üç ürünün (Üzüm, Pamuk, Mısır) ve genel gösterge olarak sayılabilecek Buğday (Durum) yıllık ürün alım fiyatı Tablo 5'de verilmiştir.

Mısır ve Buğday verileri T.M.O. , Kuru Üzüm verileri Tariş Müdürlüğü ve İzmir Ticaret Borsası kurumlarından alınmıştır. Ayrıca TÜİK verilerinden de yararlanılmıştır. 
Tablo 5. Yıllık ürün alım fiyatları (TL/ton*) (*2005 yılında TL'den altı sıfır atılmıştır. Bu sebeple 2005 yllı öncesi değerlerde bütünlüğün sağlanması için altı sıfır atılarak tabloya yerleștirilmiștir.)

\begin{tabular}{ccccc}
\hline \multicolumn{5}{c}{ Kuru } \\
Üzüm & Pamuk & Mısır & $\begin{array}{c}\text { Buğday } \\
\text { (Durum) }\end{array}$ \\
1994 & 20,00 & 25,00 & 3,18 & 3,95 \\
1995 & 40,00 & 44,00 & 6,90 & 8,69 \\
1996 & 82,50 & 73,00 & 18,60 & 18,22 \\
1997 & 160,00 & 140,00 & 32,70 & 30,78 \\
1998 & 260,00 & 195,00 & 50,70 & 50,47 \\
1999 & 405,00 & 250,00 & 71,00 & 71,38 \\
2000 & 505,00 & 422,00 & 95,30 & 100,02 \\
2001 & 930,00 & 680,00 & 155,80 & 155,32 \\
2002 & 1020,00 & 550,95 & 255,28 & 250,71 \\
2003 & 1260,00 & 783,72 & 322,76 & 333,82 \\
2004 & 1050,00 & 885,63 & 353,31 & 367,55 \\
2005 & 1160,00 & 720,00 & 260,00 & 360,00 \\
2006 & 1320,00 & 760,00 & 360,00 & 360,00 \\
2007 & 1520,00 & 740,00 & 400,00 & 430,00 \\
2008 & 1710,00 & 770,00 & 430,00 & 610,00 \\
2009 & 1980,00 & 790,00 & 450,00 & 540,00 \\
2010 & 2670,00 & 1230,00 & 490,00 & 540,00 \\
2011 & 3640,00 & 1880,00 & 540,00 & 590,00 \\
2012 & 3280,00 & 1230,00 & 590,00 & 610,00 \\
\hline
\end{tabular}

\subsubsection{Enflasyon}

Enflasyon, fiyatlar genel düzeyinin devamlı olarak yükselmesi nedeniyle paranın sürekli olarak değer kaybetmesi veya tüketicilerin satın alma gücünü yitirmesidir. $\mathrm{Bu}$ tanımdan anlaşıldığı üzere enflasyon sadece belli bir malın veya hizmetin fiyatının tek başına artması değil, fiyatların genel düzeyinin sürekli bir artış göstermesidir. Bir ekonomide bazı malların fiyatları artarken bazıları da düşmektedir. Önemli olan ise, ortalama fiyatların seyridir.

Enflasyon oranı, ülke genelindeki fiyat artışlarının ölçüsü olarak kullanılan fiyat endekslerinden yararlanılarak bulunur. Çalışmada enflasyon oranı yani fiyatlar genel düzeyindeki değişim oranı olarak Tüketici Fiyatları Endeksi değişim oranları kullanılmıştır. 1994-2012 yılları arasındaki Türkiye'deki yıllık ortalama
T.Ü.F.E. değişim oranları Tablo 6'de verilmiştir. Veriler TÜİK kurumundan alınmıştır [11].

Tablo 6. Türkiye'de yıllık ortalama T.Ü.F.E.

\begin{tabular}{|c|c|c|c|}
\hline Yillar & $\begin{array}{l}\text { T.ÜU.F.E } \\
\text { Değeri }\end{array}$ & Yillar & $\begin{array}{l}\text { T.ÜU.F.E } \\
\text { Değeri }\end{array}$ \\
\hline 1994 & 120,30 & 2004 & 9,30 \\
\hline 1995 & 76,05 & 2005 & 7,72 \\
\hline 1996 & 79,80 & 2006 & 9,93 \\
\hline 1997 & 99,10 & 2007 & 8,39 \\
\hline 1998 & 69,70 & 2008 & 10,06 \\
\hline 1999 & 68,80 & 2009 & 6,53 \\
\hline 2000 & 39,00 & 2010 & 6,40 \\
\hline 2001 & 68,50 & 2011 & 10,45 \\
\hline 2002 & 29,80 & 2012 & 6,16 \\
\hline 2003 & 18,40 & & \\
\hline
\end{tabular}

\subsubsection{Fiyat Endekslemesi}

Türkiye'deki yıllık ortalama enflasyon değerleri dikkate alınarak hesaplanan endeks değerleri Tablo 7'de verilmiştir. Tablodaki enflasyon değerleri tüketici fiyatları endeksi (T.Ü.F.E) cinsinden ve endeksleme 1994 yılındaki değer baz alınarak hesaplanmıştır.

Tablo 7. Ylllık ortalama enflasyon değerlerine göre 1994 yılından itibaren endeks değerleri

\begin{tabular}{cccc}
\hline Yllar & $\begin{array}{c}\text { Endeks } \\
\text { Değeri }\end{array}$ & Yllar & $\begin{array}{c}\text { Endeks } \\
\text { Değeri }\end{array}$ \\
1994 & 1,00 & 2004 & 143,16 \\
1995 & 2,20 & 2005 & 156,47 \\
1996 & 3,88 & 2006 & 168,55 \\
1997 & 6,97 & 2007 & 185,28 \\
1998 & 13,88 & 2008 & 200,83 \\
1999 & 23,56 & 2009 & 221,03 \\
2000 & 39,77 & 2010 & 235,47 \\
2001 & 55,28 & 2011 & 250,54 \\
2002 & 93,15 & 2012 & 276,72 \\
2003 & 120,91 & & \\
\hline
\end{tabular}

Tablo 5'deki yıllık ürün alım fiyatlarının, Tablo 7'deki fiyat endeksine oranlanmasıyla elde edilen ürün alım fiyatlarının alım gücü endeksi değerleri Tablo 8'da verilmiștir. 

Suyu Talebine Etkileri

Tablo 8. Alım gücü endeksi değerleri

\begin{tabular}{ccccc}
\hline Yıllar & $\begin{array}{c}\text { Kuru } \\
\text { Üzüm }\end{array}$ & Pamuk & Mısır & $\begin{array}{c}\text { Buğday } \\
\text { (Durum) }\end{array}$ \\
1994 & 20,000 & 25,000 & 3,180 & 3,947 \\
1995 & 18,157 & 19,973 & 3,132 & 3,943 \\
1996 & 21,272 & 18,822 & 4,796 & 4,699 \\
1997 & 22,945 & 20,076 & 4,689 & 4,414 \\
1998 & 18,727 & 14,045 & 3,652 & 3,635 \\
1999 & 17,189 & 10,611 & 3,013 & 3,030 \\
2000 & 12,698 & 10,611 & 2,396 & 2,515 \\
2001 & 16,823 & 12,301 & 2,818 & 2,810 \\
2002 & 10,950 & 5,915 & 2,741 & 2,691 \\
2003 & 10,421 & 6,482 & 2,669 & 2,761 \\
2004 & 7,335 & 6,186 & 2,468 & 2,567 \\
2005 & 7,414 & 4,602 & 1,662 & 2,301 \\
2006 & 7,832 & 4,509 & 2,136 & 2,136 \\
2007 & 8,204 & 3,994 & 2,159 & 2,321 \\
2008 & 8,515 & 3,834 & 2,141 & 3,037 \\
2009 & 8,958 & 3,574 & 2,036 & 2,443 \\
2010 & 11,339 & 5,224 & 2,081 & 2,293 \\
2011 & 14,529 & 7,504 & 2,155 & 2,355 \\
2012 & 11,853 & 4,445 & 2,132 & 2,204 \\
\hline
\end{tabular}

Tablo 8'de görüldüğü üzere, yıllar içinde endeks değerlerinde yaşanan dalgalanmalar sonucu, kuru üzümün alım endeksinin yaklaşık yarı yarıya düştüğü, pamuğun alım endeksinin ise yaklaşık \%82 düşerek en fazla değer kaybına uğrayan ürün olduğu görülmektedir. Öte yandan, mısır yaklaşık \%33, buğday ise \%44 değer kaybı yaşamıștır. Bu açıdan bakıldığında işçilik maliyeti yüksek olan pamuk yerine girdi maliyetleri açısından daha uygun olan ve düșük ișçilik ile yetiştirilebilen mısırın tercih edilmeye başlanmasının nedenlerinden biri de budur denilebilir.

\subsection{Toplam alanlar açısından irdeleme}

Gediz Havzasında bulunan tüm sulama birliklerindeki toplam pamuk, misır ve bağ sulama alanlarındaki 1995-2012 yılları arasındaki değişim (ha) Tablo 9, 11 ve 13' de verilmiștir. Bu veriler DSİ 2. Bölge Müdürlügünden temin edilmiştir.
Gediz Havzası geneline bakıldığında bölgede 2000 yılına kadar esas olarak pamuk ve bağ alanlarının çokluğu göze çarpmaktadır. Mısır sulama alanları bu iki ürüne klyasla daha az yer tutmaktadır. 2000 yılından itibaren mısır sulama alanlarında kayda değer artışlar gözlenmektedir. 2006 yılından itibaren ise misır sulama alanları pamuk sulama alanlarını geçip bağ sulama alanları ile eşitlenmiştir. 2007 yılından itibaren ise bölgedeki en büyük sulama alanına sahip ürün konumuna gelmiştir.

Tablo 9, 10, 11, 12, 13 ve 14 incelendiğinde havza genelinde etkin olarak pamuk, bağ ve misır ekildiği görülmektedir. Ekilen alanların yaklaşık \%90'ını oluşturan bu üç ürün dışında havzada meyve, sebze, hububat vb. gibi ürünler de ekilmekte yalnız bu ürünlerin havza genelinde toplam ekim oranları küçük yüzdelerde kalmakta ve bu oranlarda yıldan yıla önemli değişimler gözlenmemektedir. 
C.P. Çetinkaya vd. / Gediz Havzası'nda Yıllık Bitki Deseni Değişimlerinin Ekonomik Nedenleri ve Sulama Suyu Talebine Etkileri

Tablo 9. Toplam sulanan pamuk alanları ve alım gücü endeksleri

\begin{tabular}{cccccc}
\hline Yıllar & $\begin{array}{c}\text { Yllık Ortalama } \\
\text { Enflasyon }\end{array}$ & $\begin{array}{c}\text { 1994 Ylı Baz } \\
\text { Fiyat Endeksi }\end{array}$ & $\begin{array}{c}\text { Pamuk Alım Fiyatları } \\
\text { (TL/Ton) }\end{array}$ & $\begin{array}{c}\text { Alım } \\
\text { Gücü }\end{array}$ & $\begin{array}{c}\text { Ekim Alanları } \\
\text { (ha) }\end{array}$ \\
1994 & 120,30 & 1,00 & 25,000 & 25,0000 & -- \\
1995 & 76,05 & 2,20 & 44,000 & 19,9728 & 35936,00 \\
1996 & 79,80 & 3,88 & 73,000 & 18,8223 & 36598,00 \\
1997 & 99,10 & 6,97 & 140,000 & 20,0765 & 32517,00 \\
1998 & 69,70 & 13,88 & 195,000 & 14,0450 & 35051,00 \\
1999 & 68,80 & 23,56 & 250,000 & 10,6108 & 32065,00 \\
2000 & 39,00 & 39,77 & 422,000 & 10,6108 & 26666,00 \\
2001 & 68,50 & 55,28 & 680,000 & 12,3007 & 31163,00 \\
2002 & 29,80 & 93,15 & 550,952 & 5,9147 & 32055,00 \\
2003 & 18,40 & 120,91 & 783,722 & 6,4820 & 28490,00 \\
2004 & 9,30 & 143,16 & 885,628 & 6,1865 & 27300,00 \\
2005 & 7,72 & 156,47 & 720,000 & 4,6016 & 24426,65 \\
2006 & 9,93 & 168,55 & 760,000 & 4,5091 & 21553,30 \\
2007 & 8,39 & 185,28 & 740,000 & 3,9939 & 10621,22 \\
2008 & 10,06 & 200,83 & 770,000 & 3,8341 & 6845,79 \\
2009 & 6,53 & 221,03 & 790,000 & 3,5741 & 6979,82 \\
2010 & 6,40 & 235,47 & 1230,000 & 5,2237 & 12184,92 \\
2011 & 10,45 & 250,54 & 1880,000 & 7,5039 & 6782,61 \\
2012 & 6,16 & 276,72 & 1230,000 & 4,4450 & 1380,30 \\
\hline
\end{tabular}

Tablo 10. Sulanan pamuk alanları (n+1. yıl) ve alım gücü endeksi (n. yıl)

\begin{tabular}{ccccccc}
\hline Yllar & $\begin{array}{c}\text { Yllık Ortalama } \\
\text { Enflasyon }\end{array}$ & $\begin{array}{c}\text { 1994 Yılı } \\
\text { Baz Fiyat } \\
\text { Endeksi }\end{array}$ & $\begin{array}{c}\text { Pamuk Alım } \\
\text { Fiyatları } \\
\text { (TL/Ton) }\end{array}$ & $\begin{array}{c}\text { Alım } \\
\text { Gücü }\end{array}$ & $\begin{array}{c}\text { Ekim Alanı } \\
\text { Yllar }\end{array}$ & $\begin{array}{c}\text { Ekim Alanları } \\
\text { (ha) }\end{array}$ \\
1994 & 120,30 & 1,00 & 25,000 & 25,0000 & 1995 & 35936,00 \\
1995 & 76,05 & 2,20 & 44,000 & 19,9728 & 1996 & 36598,00 \\
1996 & 79,80 & 3,88 & 73,000 & 18,8223 & 1997 & 32517,00 \\
1997 & 99,10 & 6,97 & 140,000 & 20,0765 & 1998 & 35051,00 \\
1998 & 69,70 & 13,88 & 195,000 & 14,0450 & 1999 & 32065,00 \\
1999 & 68,80 & 23,56 & 250,000 & 10,6108 & 2000 & 26666,00 \\
2000 & 39,00 & 39,77 & 422,000 & 10,6108 & 2001 & 31163,00 \\
2001 & 68,50 & 55,28 & 680,000 & 12,3007 & 2002 & 32055,00 \\
2002 & 29,80 & 93,15 & 550,952 & 5,9147 & 2003 & 28490,00 \\
2003 & 18,40 & 120,91 & 783,722 & 6,4820 & 2004 & 27300,00 \\
2004 & 9,30 & 143,16 & 885,628 & 6,1865 & 2005 & 24426,65 \\
2005 & 7,72 & 156,47 & 720,000 & 4,6016 & 2006 & 21553,30 \\
2006 & 9,93 & 168,55 & 760,000 & 4,5091 & 2007 & 10621,22 \\
2007 & 8,39 & 185,28 & 740,000 & 3,9939 & 2008 & 6845,79 \\
2008 & 10,06 & 200,83 & 770,000 & 3,8341 & 2009 & 6979,82 \\
2009 & 6,53 & 221,03 & 790,000 & 3,5741 & 2010 & 12184,92 \\
2010 & 6,40 & 235,47 & 1230,000 & 5,2237 & 2011 & 6782,61 \\
2011 & 10,45 & 250,54 & 1880,000 & 7,5039 & 2012 & 1380,30 \\
2012 & 6,16 & 276,72 & 1230,000 & 4,4450 & & \\
\hline
\end{tabular}


Tablo 9, 10 incelendiğinde 2006 yllına kadar trend ürün olan Pamuk, 2006 yılından itibaren sulama alanlarında \%96'llk bir düșüșe uğramıștır. Bu değişiklikte, çizelgede görülen pamuk alım gücü endeksindeki yaklaşık \%82'lik düşüşün etkisi de bulunmaktadır.

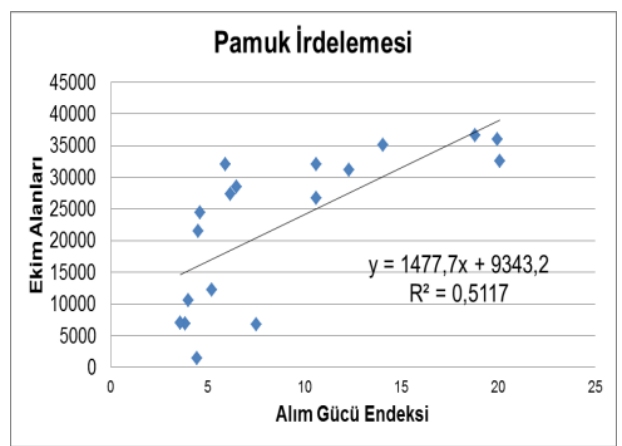

Şekil 8. Sulanan pamuk alanlarının alım gücü endeksine göre değişimi

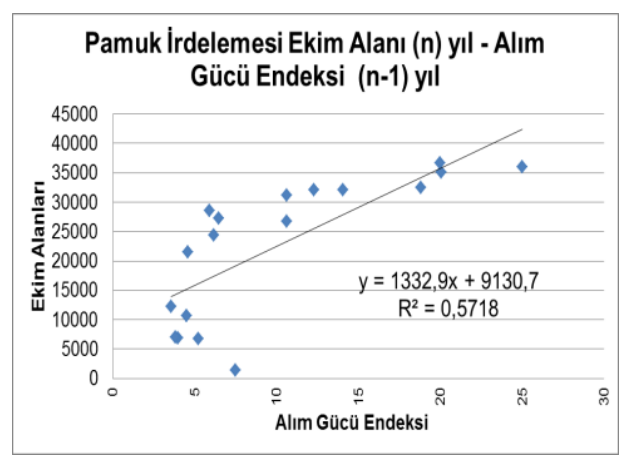

Şekil 9. Sulanan pamuk alanlarının bir önceki yılın alım gücü endeksine göre değişimi

Şekil 8 incelendiğinde toplam sulanan pamuk alanlarında alım gücü endeksi ve ekim alanları arasında doğrusal bir iliş̧i olduğu görülmektedir. Benzer ilişki bir önceki yıl alım gücü endeks değerleri ve ekim alanları için de geçerlidir (Şekil 9). Dolayısıyla yıllar içinde alım endeksi değerlerinin düşüşüyle ekim alanları da azalmıştır.

Tablo 11. Sulanan mısır alanları ve alım gücü endeksleri

\begin{tabular}{cccccc}
\hline Yllar & $\begin{array}{c}\text { Yllık Ortalama } \\
\text { Enflasyon }\end{array}$ & $\begin{array}{c}\text { 1994 Yllı Baz Fiyat } \\
\text { Endeksi }\end{array}$ & $\begin{array}{c}\text { Misır Alım Fiyatlarl } \\
\text { (TL/Ton) }\end{array}$ & $\begin{array}{c}\text { Alım } \\
\text { Gücü }\end{array}$ & $\begin{array}{c}\text { Ekim Alanı } \\
\text { (ha) }\end{array}$ \\
1994 & 120,30 & 1,00 & 3,180 & 3,1800 & --- \\
1995 & 76,05 & 2,20 & 6,900 & 3,1321 & 997,00 \\
1996 & 79,80 & 3,88 & 18,600 & 4,7958 & 1522,00 \\
1997 & 99,10 & 6,97 & 32,700 & 4,6893 & 2689,00 \\
1998 & 69,70 & 13,88 & 50,700 & 3,6517 & 2568,00 \\
1999 & 68,80 & 23,56 & 71,000 & 3,0135 & 3314,00 \\
2000 & 39,00 & 39,77 & 95,300 & 2,3962 & 5683,00 \\
2001 & 68,50 & 55,28 & 155,800 & 2,8183 & 4424,00 \\
2002 & 29,80 & 93,15 & 255,279 & 2,7405 & 5671,00 \\
2003 & 18,40 & 120,91 & 322,761 & 2,6695 & 7790,00 \\
2004 & 9,30 & 143,16 & 353,305 & 2,4680 & 9822,00 \\
2005 & 7,72 & 156,47 & 260,000 & 1,6617 & 12907,36 \\
2006 & 9,93 & 168,55 & 360,000 & 2,1359 & 15992,72 \\
2007 & 8,39 & 185,28 & 400,000 & 2,1588 & 18360,54 \\
2008 & 10,06 & 200,83 & 430,000 & 2,1411 & 12593,94 \\
2009 & 6,53 & 221,03 & 450,000 & 2,0359 & 15135,99 \\
2010 & 6,40 & 235,47 & 490,000 & 2,0810 & 17073,32 \\
2011 & 10,45 & 250,54 & 540,000 & 2,1554 & 17890,26 \\
2012 & 6,16 & 276,72 & 590,000 & 2,1321 & 18707,20 \\
\hline
\end{tabular}


C.P. Çetinkaya vd. / Gediz Havzası'nda Yıllık Bitki Deseni Değişimlerinin Ekonomik Nedenleri ve Sulama Suyu Talebine Etkileri

Tablo 12. Sulanan mısır alanları ( $\mathrm{n}+1$. yıl) ve alım gücü endeksi (n. yıl)

\begin{tabular}{ccccccc}
\hline Yillar & $\begin{array}{c}\text { Ylllk Ortalama } \\
\text { Enflasyon }\end{array}$ & $\begin{array}{c}\text { 1994 Yllı Baz } \\
\text { Fiyat Endeksi }\end{array}$ & $\begin{array}{c}\text { Misır Alım } \\
\text { Fiyatları } \\
\text { (TL/Ton) }\end{array}$ & $\begin{array}{c}\text { Alım } \\
\text { Gücü }\end{array}$ & $\begin{array}{c}\text { Ekim } \\
\text { Alanı } \\
\text { Ylllar }\end{array}$ & $\begin{array}{c}\text { Ekim } \\
\text { Alanları (ha) }\end{array}$ \\
1994 & 120,30 & 1,00 & 3,180 & 3,1800 & 1995 & 997,00 \\
1995 & 76,05 & 2,20 & 6,900 & 3,1321 & 1996 & 1522,00 \\
1996 & 79,80 & 3,88 & 18,600 & 4,7958 & 1997 & 2689,00 \\
1997 & 99,10 & 6,97 & 32,700 & 4,6893 & 1998 & 2568,00 \\
1998 & 69,70 & 13,88 & 50,700 & 3,6517 & 1999 & 3314,00 \\
1999 & 68,80 & 23,56 & 71,000 & 3,0135 & 2000 & 5683,00 \\
2000 & 39,00 & 39,77 & 95,300 & 2,3962 & 2001 & 4424,00 \\
2001 & 68,50 & 55,28 & 155,800 & 2,8183 & 2002 & 5671,00 \\
2002 & 29,80 & 93,15 & 255,279 & 2,7405 & 2003 & 7790,00 \\
2003 & 18,40 & 120,91 & 322,761 & 2,6695 & 2004 & 9822,00 \\
2004 & 9,30 & 143,16 & 353,305 & 2,4680 & 2005 & 12907,36 \\
2005 & 7,72 & 156,47 & 260,000 & 1,6617 & 2006 & 15992,72 \\
2006 & 9,93 & 168,55 & 360,000 & 2,1359 & 2007 & 18360,54 \\
2007 & 8,39 & 185,28 & 400,000 & 2,1588 & 2008 & 12593,94 \\
2008 & 10,06 & 200,83 & 430,000 & 2,1411 & 2009 & 15135,99 \\
2009 & 6,53 & 221,03 & 450,000 & 2,0359 & 2010 & 17073,32 \\
2010 & 6,40 & 235,47 & 490,000 & 2,0810 & 2011 & 17890,26 \\
2011 & 10,45 & 250,54 & 540,000 & 2,1554 & 2012 & 18707,20 \\
2012 & 6,16 & 276,72 & 590,000 & 2,1321 & & \\
\hline
\end{tabular}

Tablo 11 incelendiğinde, misır sulama alanlarının yıllar içinde \%95 arttı̆̆ görülmektedir. Her ne kadar alım gücü endeksinde \%33'lük bir düşüş yaşansa da işçilik kolaylığı ve teşvik benzeri faktörlerle havzanın ana ürünleri arasında öne çıkmıștır. Öte yandan alım gücü endeksi değerlerinin yıllar içinde küçük oranlardaki düşüşü bir sonraki yıl ekim alanlarının da düşüşüne sebep olmamıştır (Tablo 12).

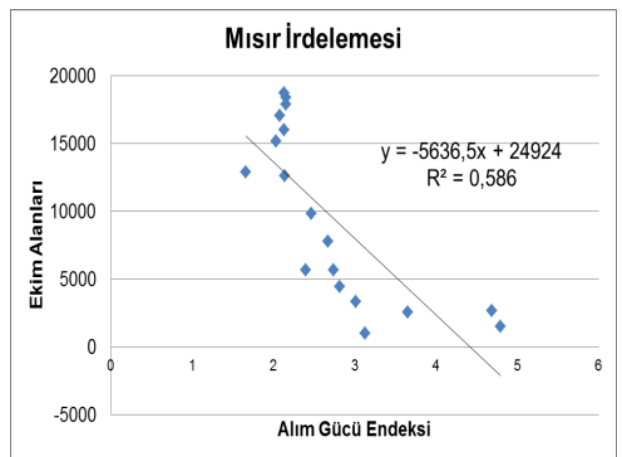

Şekil 10. Sulanan mısır alanlarının alım gücü endeksine göre değișimi

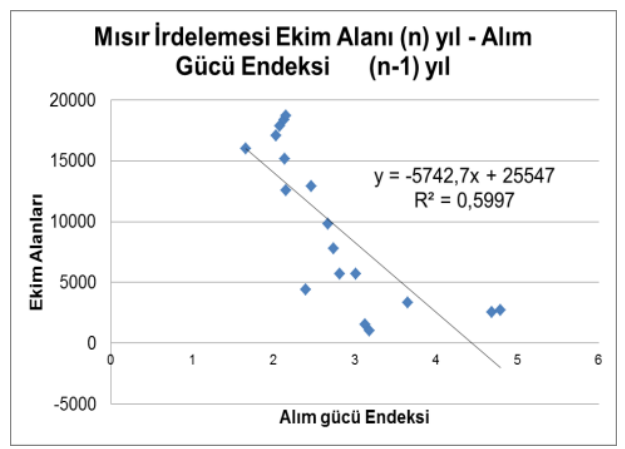

Şekil 11. Sulanan mısır alanlarının bir önceki yılın alım gücü endeksine göre değișimi

Şekil 10 ve şekil 11 incelendiğinde her ne kadar mısır ekim alanları ve alım gücü endeksi arasında ters bir ilişki olduğu söylenebilecek olsa da, bu ilişkinin etkisinin önemsenmeyecek derecede küçük olduğu da görülmektedir. Mısır ekim alanları ve alım gücü endeksi ne bulunduğu ne de bir önceki yıldaki değerlerinden etkilenmeden istikrarlı bir şekilde arttığı görülmektedir. 
C.P. Çetinkaya vd. / Gediz Havzası'nda Yıllık Bitki Deseni Değişimlerinin Ekonomik Nedenleri ve Sulama Suyu Talebine Etkileri

Tablo 13. Sulanan bağ alanları ve alım gücü endeksleri

\begin{tabular}{|c|c|c|c|c|c|c|}
\hline Yillar & $\begin{array}{l}\text { Yillık Ortalama } \\
\text { Enflasyon }\end{array}$ & $\begin{array}{l}1994 \text { Yılı Baz } \\
\text { Fiyat Endeksi }\end{array}$ & \multicolumn{2}{|c|}{$\begin{array}{l}\text { Üzüm Alım Fiyatları } \\
\text { (TL/Ton) }\end{array}$} & $\begin{array}{l}\text { Alım } \\
\text { Gücü }\end{array}$ & $\begin{array}{c}\text { Ekim Alanları } \\
\text { (ha) }\end{array}$ \\
\hline 1994 & 120,30 & 1,00 & \multicolumn{2}{|c|}{20,000} & 20,0000 & --- \\
\hline 1995 & 76,05 & 2,20 & \multicolumn{2}{|c|}{40,000} & 18,1571 & 16045,00 \\
\hline 1996 & 79,80 & 3,88 & \multicolumn{2}{|c|}{82,500} & 21,2718 & 16383,00 \\
\hline 1997 & 99,10 & 6,97 & \multicolumn{2}{|c|}{160,000} & 22,9446 & 15042,00 \\
\hline 1998 & 69,70 & 13,88 & \multicolumn{2}{|c|}{260,000} & 18,7267 & 16064,00 \\
\hline 1999 & 68,80 & 23,56 & \multicolumn{2}{|c|}{405,000} & 17,1894 & 15876,00 \\
\hline 2000 & 39,00 & 39,77 & \multicolumn{2}{|c|}{505,000} & 12,6977 & 18115,00 \\
\hline 2001 & 68,50 & 55,28 & \multicolumn{2}{|c|}{930,000} & 16,8230 & 18476,00 \\
\hline 2002 & 29,80 & 93,15 & \multicolumn{2}{|c|}{1020,000} & 10,9501 & 19313,80 \\
\hline 2003 & 18,40 & 120,91 & \multicolumn{2}{|c|}{1260,000} & 10,4211 & 18099,00 \\
\hline 2004 & 9,30 & 143,16 & \multicolumn{2}{|c|}{1050,000} & 7,3347 & 18421,00 \\
\hline 2005 & 7,72 & 156,47 & \multicolumn{2}{|c|}{1160,000} & 7,4136 & 19785,59 \\
\hline 2006 & 9,93 & 168,55 & \multicolumn{2}{|c|}{1320,000} & 7,8316 & 21150,18 \\
\hline 2007 & 8,39 & 185,28 & \multicolumn{2}{|c|}{1520,000} & 8,2036 & 17465,13 \\
\hline 2008 & 10,06 & 200,83 & \multicolumn{2}{|c|}{1710,000} & 8,5147 & 15276,77 \\
\hline 2009 & 6,53 & 221,03 & \multicolumn{2}{|c|}{1980,000} & 8,9579 & 17899,79 \\
\hline 2010 & 6,40 & 235,47 & \multicolumn{2}{|c|}{2670,000} & 11,3392 & 15953,44 \\
\hline 2011 & 10,45 & 250,54 & \multicolumn{2}{|c|}{3640,000} & 14,5288 & 16578,07 \\
\hline 2012 & 6,16 & 276,72 & \multicolumn{2}{|c|}{3280,000} & 11,8532 & 17202,70 \\
\hline Yillar & $\begin{array}{l}\text { Yıllık Ortalama } \\
\text { Enflasyon }\end{array}$ & $\begin{array}{c}1994 \text { Yılı } \\
\text { Baz Fiyat } \\
\text { Endeksi }\end{array}$ & $\begin{array}{c}\text { Üzüm Alım } \\
\text { Fiyatları } \\
\text { (TL/Ton) }\end{array}$ & Alım Gücü & $\begin{array}{l}\text { Ekim } \\
\text { Alanı } \\
\text { Yıllar }\end{array}$ & $\begin{array}{c}\text { Ekim } \\
\text { Alanları (ha) }\end{array}$ \\
\hline 1994 & 120,30 & 1,00 & 20,000 & 20,0000 & 1995 & 16045,00 \\
\hline 1995 & 76,05 & 2,20 & 40,000 & 18,1571 & 1996 & 16383,00 \\
\hline 1996 & 79,80 & 3,88 & 82,500 & 21,2718 & 1997 & 15042,00 \\
\hline 1997 & 99,10 & 6,97 & 160,000 & 22,9446 & 1998 & 16064,00 \\
\hline 1998 & 69,70 & 13,88 & 260,000 & 18,7267 & 1999 & 15876,00 \\
\hline 1999 & 68,80 & 23,56 & 405,000 & 17,1894 & 2000 & 18115,00 \\
\hline 2000 & 39,00 & 39,77 & 505,000 & 12,6977 & 2001 & 18476,00 \\
\hline 2001 & 68,50 & 55,28 & 930,000 & 16,8230 & 2002 & 19313,80 \\
\hline 2002 & 29,80 & 93,15 & 1020,000 & 10,9501 & 2003 & 18099,00 \\
\hline 2003 & 18,40 & 120,91 & 1260,000 & 10,4211 & 2004 & 18421,00 \\
\hline 2004 & 9,30 & 143,16 & 1050,000 & 7,3347 & 2005 & 19785,59 \\
\hline 2005 & 7,72 & 156,47 & 1160,000 & 7,4136 & 2006 & 21150,18 \\
\hline 2006 & 9,93 & 168,55 & 1320,000 & 7,8316 & 2007 & 17465,13 \\
\hline 2007 & 8,39 & 185,28 & 1520,000 & 8,2036 & 2008 & 15276,77 \\
\hline 2008 & 10,06 & 200,83 & 1710,000 & 8,5147 & 2009 & 17899,79 \\
\hline 2009 & 6,53 & 221,03 & 1980,000 & 8,9579 & 2010 & 15953,44 \\
\hline 2010 & 6,40 & 235,47 & 2670,000 & 11,3392 & 2011 & 16578,07 \\
\hline 2011 & 10,45 & 250,54 & 3640,000 & 14,5288 & 2012 & 17202,70 \\
\hline 2012 & 6,16 & 276,72 & 3280,000 & 11,8532 & & \\
\hline
\end{tabular}


C.P. Çetinkaya vd. / Gediz Havzası'nda Yıllık Bitki Deseni Değişimlerinin Ekonomik Nedenleri ve Sulama Suyu Talebine Etkileri

Bağ sulama alanlarının alım gücü endeksi değerleri yıllar içinde yarı yarıya azalmış olsa da ekim alanlarının yaklaşık aynı kaldığı görülmektedir (Tablo 13). Tablo 14' e bakıldığında ise, çiftçinin bir önceki yıl alım gücü endeksine göre ekim alanlarına karar vermediği görülmektedir.

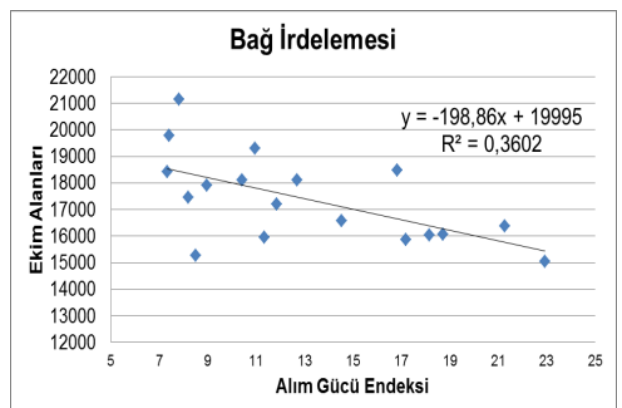

Şekil 12. Sulanan bağ alanlarının alım gücü endeksine göre değişimi

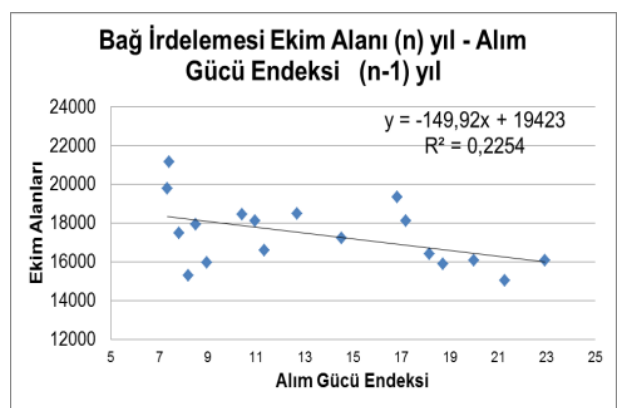

Şekil 13. Sulanan bağ alanlarının bir önceki yılın alım gücü endeksine göre değișimi

Şekil 12 ve 13'e bakıldığında, bağ ekim alanları ve alım gücü endeksleri arasında, misıra benzer bir durum gözlenmektedir. Aralarındaki ilişki her ne kadar ters olduğu görülse de mertebesi nedeniyle önemsenmeyecek düzeydedir. Bağ alanları, alım gücü endeksi değerlerinin düşmesine rağmen sabit kalmıştır.

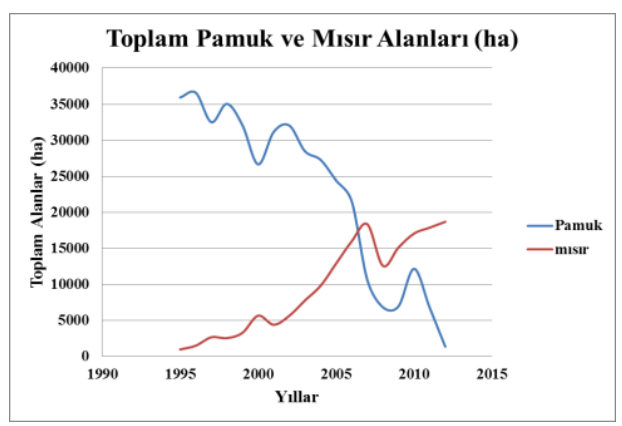

Şekil 14. Sulanan pamuk ve misır ekim alanları

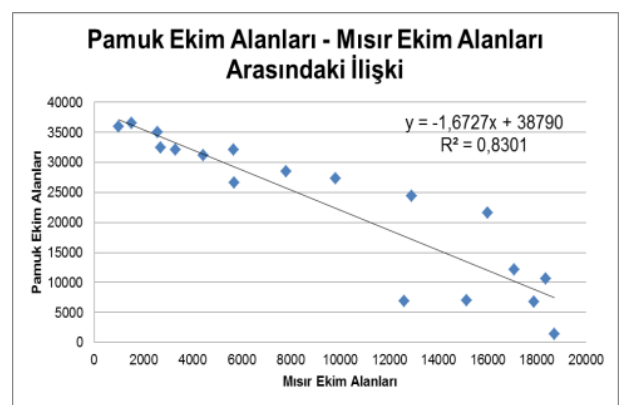

Şekil 15. Sulanan pamuk alanları ile aynı yıldaki mısır alanları arasındaki ilișki

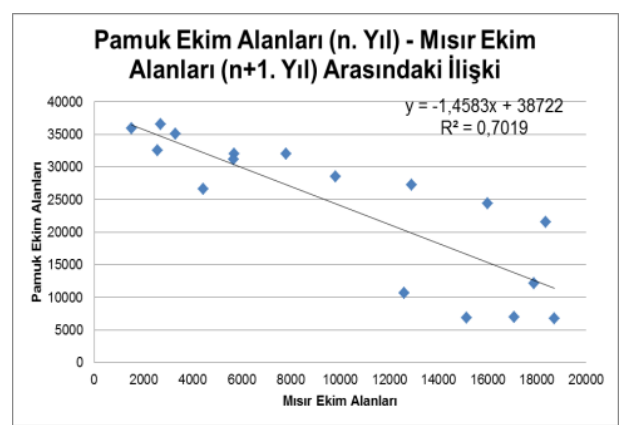

Şekil 16. Sulanan pamuk alanları ile bir yıl sonraki mısır alanları arasındaki ilişki

Şekil 14, 15 ve 16 incelendiğinde ise, yıllar içinde azalan pamuk alanlarının yerini mısırın aldığını, aralarında ters bir ilişki olduğu görülmektedir.

\subsection{Su ihtiyacı açısından irdeleme}

Gediz Havzası'nda 1995-2012 yılları arasında değişen tarımsal ürün eğilimlerini irdelemek amacı ile ekilen ürünlerin yıllar içindeki sulama suyu ihtiyaçları da hesaplanmıştır. F.A.O. organizasyonunun geliştirdiği CropWat 
C.P. Çetinkaya vd. / Gediz Havzası'nda Yıllık Bitki Deseni Değişimlerinin Ekonomik Nedenleri ve Sulama Suyu Talebine Etkileri

programı ile hesaplanan sulama suyu ihtiyaçları, Şekil 17'de ürün bazındaki yıllık toplam sulama suyu ihtiyacı, Şekil 18'de birim hektarda ürün bazındaki yıllık sulama suyu ihtiyacı olarak gösterilmiştir. Ş̧ekillerden görüldüğü üzere, yıllar içinde pamuk ekim alanları yerini mısıra bırakmıș, bağ alanlarında ise kayda değer bir değişim olmamıştır. Şekil 19'da tüm ürünlerin aylık toplam sulama suyu ihtiyacının yıllara göre değișimi, Şekil 20'de ise tüm ürünlerin yıllık toplam sulama suyu ihtiyacının yıllara göre değişimi görülmektedir. Aylık grafiklerde sadece sulama sezonuna (Haziran-Ağustos) odaklanılmıș, diğer aylar sunulmamıștır.

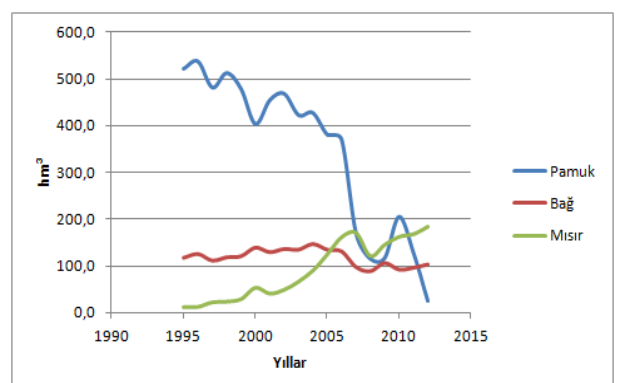

Şekil 17. Yıllara göre pamuk, mısır ve bağ toplam sulama suyu ihtiyaçları

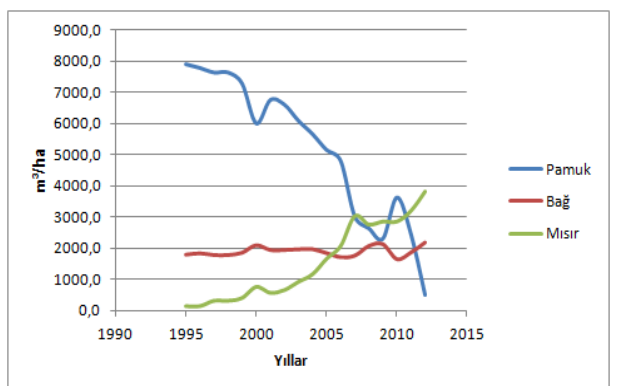

Sekil 18. Yıllara göre pamuk, mısır ve bağ birim alan sulama suyu ihtiyaçları

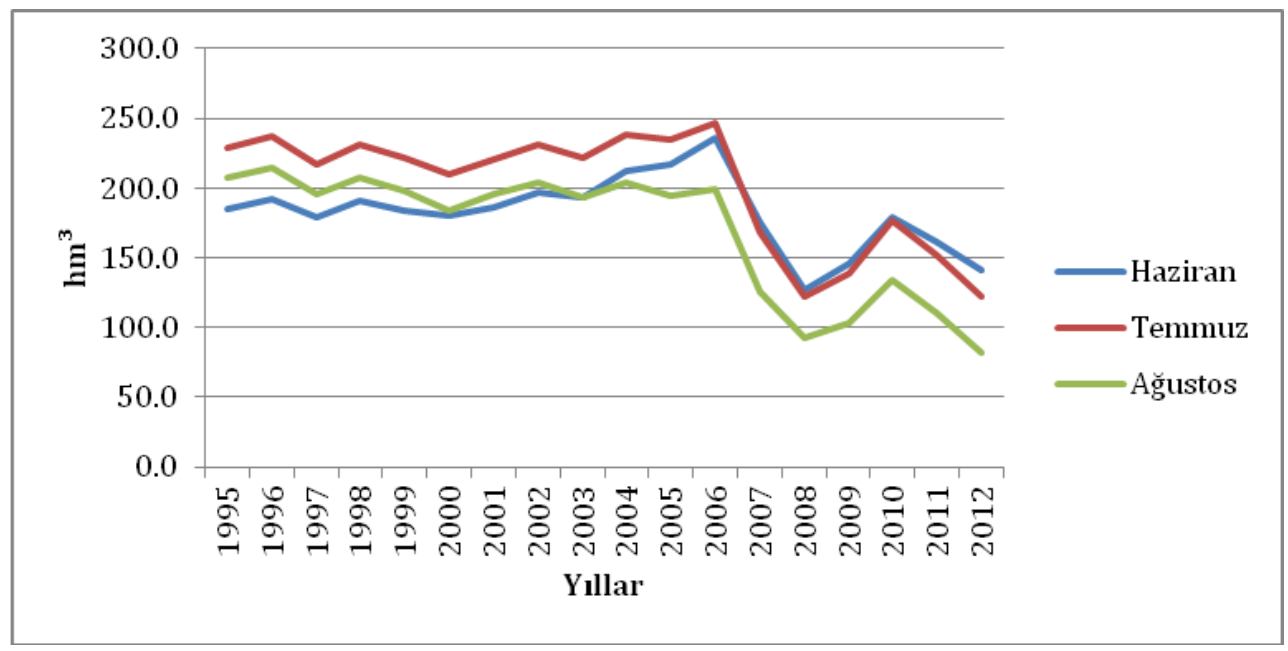

Şekil 19. Sulama sezonu aylarına göre yıllar içindeki toplam sulama suyu ihtiyacı değișimleri 

Suyu Talebine Etkileri

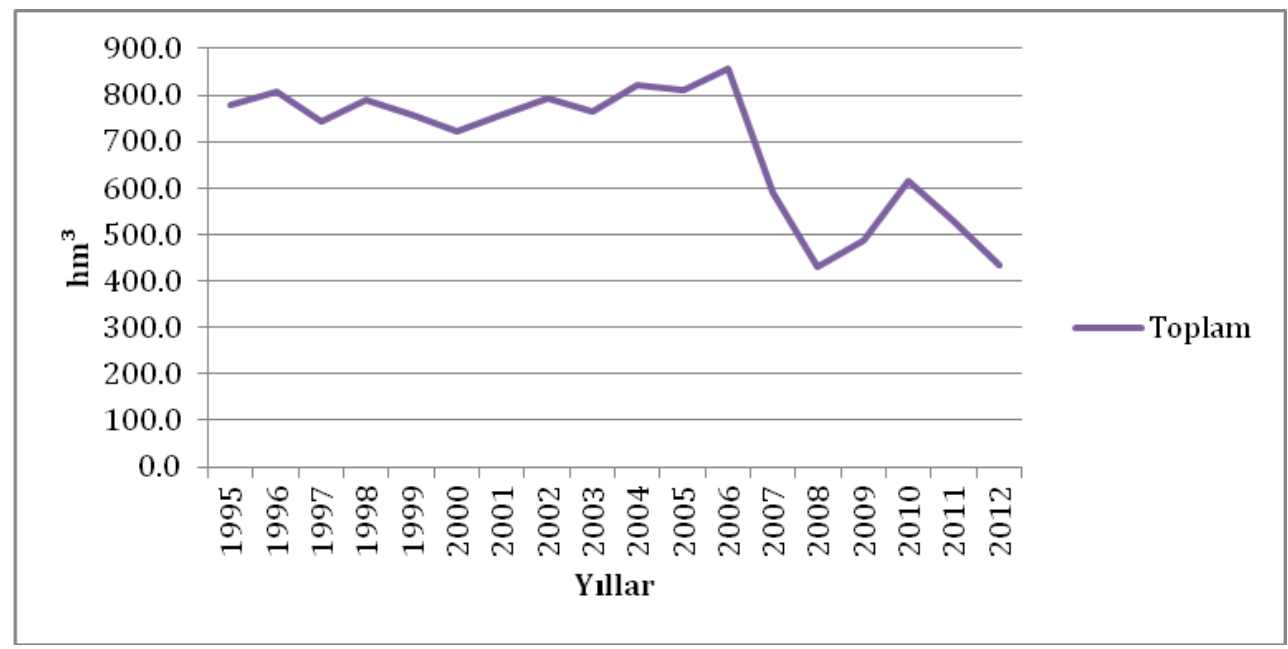

Şekil 20. Toplam sulama suyu ihtiyacının yıllar içindeki değişimi

\section{Tartışma}

Gediz Havzası'nda yıllara göre sulanan ürün alanlarının 1995-2006 yılları arasında yükselme eğilimindeyken 2007 yılından sonra düşüşe geçtiği görülmektedir (Şekil 2). $\mathrm{Bu}$ düşüş havzadaki ana ürünler olan; pamuk, mısır ve bağın sulama alanlarının yıllar içindeki değişiminde açıkça görülmektedir (Şekil 3,4,5). Havzadaki ürünlerin alan yüzdelerine bakıldığında ise ana ürünler dişındaki ürünlerde yüzde olarak büyük değişimlerin olmadığı, yıldan yıla değişimlerin oluştuğu ve ortalama olarak aynı değerlerde seyrettiği görülmektedir.

Gediz Havzası'ndaki hâkim ürünlerde (pamuk, misır ve bağ) yapılan incelemelerde, aralarındaki ilişkinin araştırılması için doğrusal regresyon analizi uygulanmıştır.

Gediz Havzası sulamalarında pamuk sulama alanları incelendiğinde, toplam sulama alanlarında doğrusal bir azalma gözlenmektedir. 1995 yllında 36000 hektar sulama alanına sahip olan pamuk, 2001 yılında 31000 hektara gerilemiştir. Toplam sulanan pamuk alanlarının alım gücü endeksine göre değişiminin incelendiği regresyon analizi sonucunda determinasyon katsayısı değeri 0,60 mertebelerinde, ekim alanları ile bir önceki yılın alım gücü endeksi verileri grafiği incelendiğinde ise 0,64 mertebelerinde olduğu görülmüştür. Bu değer toplam pamuk sulama alanlarındaki değişim ile ürün alım fiyatları arasında kuvvetli bir bağ olduğunu ve bir önceki yıl fiyatlarının pamuk üreticisinin tercihini belirlediğini göstermektedir.

Gediz Havzası'nda misır sulama alanlarında her geçen yıl artış gözlemlenmiştir. 1995 yılında 1100 hektarlık, havza genelinde küçük sayılabilecek bir sulama sahasına sahip olan mısır, 2002 yılında 5800 hektarlık bir sulama sahasına yükselmiștir. Mısır sulama alanlarındaki bu artışın alım gücü endeksine göre değişimi incelendiğinde determinasyon katsayısı değeri 0,74 civarında bulunmuştur. Ayrıca ekim alanları ile bir önceki yılın alım gücü endeksi verileri grafiği irdelendiğinde determinasyon katsayısı 0,78 değerini bulmaktadır. Mısır sulama alanlarındaki artış ile ürün alım fiyatı arasında kuvvetli bir bağ bulunduğu görülmektedir ve bir önceki yıl fiyatının çiftçinin tercihini belirlediğini göstermektedir. 
Şekil 15 ve 16'da pamuk sulama alanları ve mısır sulama alanları arasındaki ilişki görülmektedir. $\quad \mathrm{Bu} \quad$ ilişkinin determinasyon katsayısı 0,83 değerindedir. Dolayısıyla bu ikili arasında kuvvetli bir bağ olduğu yorumlanabilir. Ylllar içinde pamuk sulama alanları, mısır sulama alanlarına dönüşmüş ve bölgedeki mısır sulama alanları sürekli artmıștır.

Gediz Havzası sulamalarında toplam sulanan bağ alanlarında ise yıllara göre bir artış gözlemlenmekte ve bazı dönemlerde düşüşler görülmektedir. 1995 yllında 16000 hektar sulama sahasına sahip olan bağ, 2006 yılında 21000 hektarlık bir alana yükselmiștir. $\mathrm{Bu}$ ylldan sonra ise düşüş yaşayarak 15000-16000 hektar seviyelerine düşmüştür. Toplam sulanan bağ alanlarının alım gücü endeksine göre değişiminin incelendiği regresyon analizi sonucunda determinasyon katsayısı 0,36 bulunmuştur. Ekim alanları ile bir önceki yıl alım gücü endeksi verileri karşılaştırıldığında ise korelasyon katsayısı değeri 0,24'e düşmektedir. Dolayısıyla üreticinin bir önceki yıl fiyatlarına göre üretimini değiștirmesi fikri için kuvvetli bir bağ kurulamamaktadır. Bu noktada toplam sulanan alanlar ile toplam sulanan bağ alanları karşılaştırıldığında daha anlamlı veriler elde edilmektedir.

Şekil 7'de görüldüğü üzere, sulanan bağ alanları ile toplam sulanan alanlar arasındaki ilişkinin korelasyon katsayısı 0,58 değerine ulaşmaktadır. Bu veride bağ alanlarındaki azalmanın toplam alanların azalmasından kaynaklandığını göstermektedir.

Alım gücü endeksi verileri incelendiğinde ise pamuktaki azalma, mısırdaki artış ve bağ alanlarındaki sabit değerler anlam kazanmaktadır. Alım gücü endeksine göre pamuk 1994 yllından 2012 yılına kadar \%80 oranında değersizleşmiştir. $\mathrm{Bu}$ da üreticinin pamuktan asıl vazgeçme sebebini açlklamaktadır. Mısır \%30, üzüm ise $\% 40$ civarlarındadır. Baz olarak incelediğimiz buğday için ise $\% 45$ tir. Görüldügü üzere misır ve üzümdeki değer kaybı buğdaydan daha azdır. Buradan mısır ve bağ ürünlerini çiftçilerin daha karlı olarak gördüğü söylenebilir. Bağcılık ile uğraşan çiftçilerin tercihi aynı ürünün tarımını sürdürmek yönünde olurken, tek yıllık bitkiler olan pamuk ve mısırın üretimi mısır lehine ikameli olarak yıllar içinde artmıştır.

Sulama suyu ihtiyacı açısından irdelendiğinde ise, 1995-2006 ylları arasında düşük de olsa artış trendinde olan toplam sulama suyu ihtiyacl, 2007 yılı sonrası hem sulama alanlarının azalması, hem de fazla sulama suyu ihtiyacl olan ürünlerin tercih edilmemesi nedeniyle genel bir düşüş göstermiștir (Şekil 20).

\section{Sonuç ve Öneriler}

Ekonomik kaygılarla değişen bitki deseni sonucu kritik sulama sezonunda bir kayma oluștuğu gözlemlenmektedir. 1995-2006 yılları arasında aylık pik sulama suyu ihtiyacl, pamuk bitkisinin maksimum sulama suyuna ihtiyaç duyduğu aylar olan temmuz ve ağustos ayları olarak görülmektedir. Bununla beraber, bitki deseninin pamuktan misıra kaymasıyla ile birlikte 2006 yllından itibaren pik ihtiyaç haziran ayına kaymıştır. Bu açıdan sulama suyu tahsisi planlamasında, özellikle su kısıtının bulunduğu yıllarda, oluşturulacak tahsis planlarında haziran ayı sulama suyu ihtiyacının göz önüne alınması önem arz etmektedir. Sonuç olarak, ekonomik kaygılarla değişen bitki deseni havzadaki toplam sulama suyu talebinde bir düşüşe neden olurken, sulama suyu tahsisi takviminde ağırlığı haziran ayına kaydırmıştır. Bu 

Suyu Talebine Etkileri

durum özellikle yıllık sulama planlaması yapan kurumlar tarfindan dikkate alınmalı ve planlama çalıșmaları buna göre yapılmalıdır. Diğer yandan azalan sulama suyu ihtiyacı suyun bol olduğu yıllarda başka sektörlere tahsis edilebilir haldedir. Özellikle yaşanan çevre sorunları dikkate alındığında tahsis edilmeyen bu suyun yaz aylarında düşük akımların arttırılması ve havzanın mansap ve orta kesimindeki doğal sulak alanlara verilmesi ile birlikte havzanın suya bağlı ekosistemini iyileştirmek ve dayanım kazanmasını sağlamak hedeflenmelidir. Kurak yıllarda ise iyi bir sulama takvimi ile havzada sulanan tarımsal alanlarda en düşük ürün kaybı ve kısıtlı sulama ile elde edilebilecek en yüksek verim hedeflenmeli, su tahsis planları buna göre tekrar yapılandırılmalıdır.

\section{Kaynakça}

[1] Harmancioğlu, N. 2004. Su Kaynakları Yönetiminde Sürdürülebilirlik Göstergeleri. IV. Ulusal Hidroloji Kongresi, İstanbulTeknik Üniversitesi, İnşaat Fakültesi, 21-25 Haziran, İstanbul.

[2] Gürses, H. 2005. Gediz Havzası'nda Sulanan Alanlardaki Ürün Deseni ve Ürün Alım Bedelleri Arasındaki İlişkinin Belirlenmesi. Dokuz Eylül Üniversitesi, Mühendislik Fakültesi, Lisans Tezi, İzmir.

[3] Hiessl, H., 1987. Risk aspect in the determination of optimal cropping patterns. Engineering reliability and risk in water resources; 124 : 485-498.
[4] Çetinkaya, C. P. Fistikoglu, O., Fedra, K., and Harmancioglu, N. B., 2008. Optimization methods applied for sustainable management of water-scarce basins. Journal of hydroinformatics;10.1:69-95.

[5] Guimarães, L. T. ve Magrini, A. 2008. A proposal of indicators for sustainable development in the management of river basins. Water Resources Management, 22 (9), 1191-1202.

[6] Walmsley, J. J. 2002. Framework for measuring sustainable development in catchment systems. Environ Manage, 29 (2), 195-206.

[7] Muir, M. A. K., Ávila, B., Mishra, A., Koen, V. 2016. Key outcomes of the inception workshop: Addressing water security, climate impacts and adaptation responses in Africa, Americas and Asia; 7s., illus., SC2015/WS/31.

[8] Duman, A.O. 2013. Aşağı Gediz Sulamalarında Bitki Deseni ve Alım Fiyatları İlişkisi, Dokuz Eylül Üniversitesi, Mühendislik Fakültesi, Lisans Tezi, İzmir.

[9] Değirmenci, İ. 2010. Su ve Toprak Kaynakları Planlaması, Poyraz Ofset, Ankara.

[10] Özgenç, N., Erdoğan, F.C. 1988. DSİ Sulamalarında Bitki Su Tüketimleri ve Sulama Suyu İhtiyaçları, DSİ Basım ve Foto-Film İşletme Müdürlüğü Matbaası, s.475, Ankara.

[11] T.Ü.İ.K., http://www.tuik.gov.tr/PreTablo.d o?alt_id=1014 